\title{
Molecular characterization and phylogenetic analysis of Ukrainian isolates of Cucumber mosaic virus based on the partial sequences of three genes
}

\author{
T. P. Shevchenko, O. V. Tymchyshyn, I. A. Kosenko, I. G. Budzanivska, \\ O. V. Shevchenko, V. P. Polishchuk \\ ESC "Institute of Biology and Medicine", Taras Shevchenko National University of Kyiv \\ 64/13, Volodymyrska Str., Kyiv, Ukraine, 01601 \\ tyvonchuk@ukr.net
}

\begin{abstract}
Aim. We carried out the phylogenetic analysis of the Ukrainian isolates of Cucumber mosaic virus using incomplete sequences of several viral genes.Methods. ELISA, RT-PCR, DNA sequencing and phylogenetic analysis. Results. The symptomatic samples of plants from different regions of Ukraine were collected and tested for CMV infection. Partial sequences of the genes encoding coat protein, movement protein and $2 b$ protein of four Ukrainian CMV isolates were amplified and analyzed. These isolates were shown to belong to subgroups IA and IB. The coat protein, movement protein and $2 \mathrm{~b}$ protein gene sequences demonstrated high intragroup homology. For isolates CMV-Ukr-28 and CMV-Ukr-58, the unique amino acid substitutions were detected in $2 \mathrm{~b}$ protein sequences which were considered independent of the host plant. Conclusions. The isolates of Cucumber mosaic virus which circulate in Ukraine and are described in this study, belong to the most widespread phylogenetic subgroups IA and IB which are also found in other European countries. The obtained data may indicate separate routes of CMV infection, as well as the ongoing virus microevolution in Ukraine.
\end{abstract}

K e y w o r d s: Cucumber mosaic virus, coat protein gene, movement protein gene, $2 \mathrm{~b}$ protein gene, phylogenetic analysis

\section{Introduction}

Cucumber mosaic virus (CMV) is a type species of the genus Cucumovirus (family Bromoviridae) and known to infect approximately 1300 species of more than 500 monoand dicotyledonous plant genera among over 100 families, with new hosts reported every year [1]. Wide dissemination of CMV suggests its success in rapid adapting to new hosts and new environments [2].

The genome of CMV is a single-stranded positive sense RNA. There are three RNA segments containing five open reading frames (ORF), which are packed in separate icosahedral particles and code for the proteins $1 \mathrm{a}$ and

(C) 2018 T. P. Shevchenko et al.; Published by the Institute of Molecular Biology and Genetics, NAS of Ukraine on behalf of Biopolymers and Cell. This is an Open Access article distributed under the terms of the Creative Commons Attribution License (http://creativecommons.org/licenses/by/4.0/), which permits unrestricted reuse, distribution, and reproduction in any medium, provided the original work is properly cited 
$2 \mathrm{a}$ (viral polymerase complex), $2 \mathrm{~b}$ (suppressor of the post-transcriptional gene silencing), $3 \mathrm{a}$ (movement protein (MP)), and coat protein (CP) [3].

According to serological relationships, peptide mapping of the coat protein, nucleic acid hybridization and nucleotide sequence identity, a number of CMV isolates have been described previously and classified into two subgroups, designated I and II [4]. The development of phylogenetic analysis methods led to a further subdivision of CMV isolates of subgroup I into subgroups IA and IB [4]. Subgroup IA and group II have worldwide distribution and the subgroup IB is restricted to Asia only [5]. The homology of nucleotide sequences of group I and group II representatives constitutes $\sim 67-77 \%$, when nucleotide sequence similarity among subgroup IA and IB strains is $92-94 \%$ or higher [2].

In Ukraine, the isolates of subgroups IA and IB were found previously [6]. The presence of subgroup II was initially reported but has not been confirmed by phylogenetic analysis [7]. However, these conclusions were based exclusively on the coat protein gene sequence as the information about the other genes was missing at the time. In this work, the additional sequences of the movement protein and $2 b$ protein genes were employed as these affect the pathogenicity of the isolate: together with the coat protein, the movement protein is involved in the cell-to-cell movement, when $2 b$ protein is a suppressor of the post-transcriptional gene silencing and also facilitates longdistance movement.

In the current work, we used incomplete sequences of three viral genes for the phylogenetic analysis of the Ukrainian isolates of
Cucumber mosaic virus. These isolates belonged to subgroups IA and IB only. The unique amino acid substitutions were detected in the $2 \mathrm{~b}$ protein sequences of two CMV isolates described here, suggesting separate routes of CMV infection and the ongoing virus microevolution in Ukraine.

\section{Materials and Methods}

Symptomatic plant samples were collected in different regions of Ukraine (Vinnytsia, Zaporizhzhia, Kyiv, Kirovohrad, Odessa, Poltava, Lviv, Ivano-Frankivsk, Cherkasy and Chernihiv) during the growing seasons of 20092016. Plants (pumpkin, squash, watermelon, melon, and cucumber) showing CMV-like symptoms of mosaic, stunting, fruit discoloration and/or malformation, were collected.

Collected samples were tested for CMV infection by a direct double-antibody sandwich enzyme-linked immunosorbent assay (DASELISA), as described by Clark and Adams (1977) [8], using CMV-specific polyclonal antibodies (Loewe, Germany). Briefly, plant leaves were ground to a powder with mortar and pestle in $0.1 \mathrm{M}$ phosphate buffered saline (PBS), $\mathrm{pH} \mathrm{7.4,} \mathrm{1:2} \mathrm{(m/v).} \mathrm{Plant} \mathrm{debris} \mathrm{was}$ removed by centrifugation at $5.000 \mathrm{~g}$ for 20 minutes at $+4^{\circ} \mathrm{C}$. The supernatant was used for ELISA. DAS-ELISA was performed according to the manufacturer's recommendations. Absorbance values at $405 \mathrm{~nm}$ were measured using a Termo Labsystems Opsis MR microtitre plate reader (USA).

Total RNA was extracted from naturally infected CMV-positive plant samples using RNeasy Plant Mini kit (Qiagen, UK). The twostep reverse transcription reaction (RT-PCR) was accomplished using pairs of specific prim- 

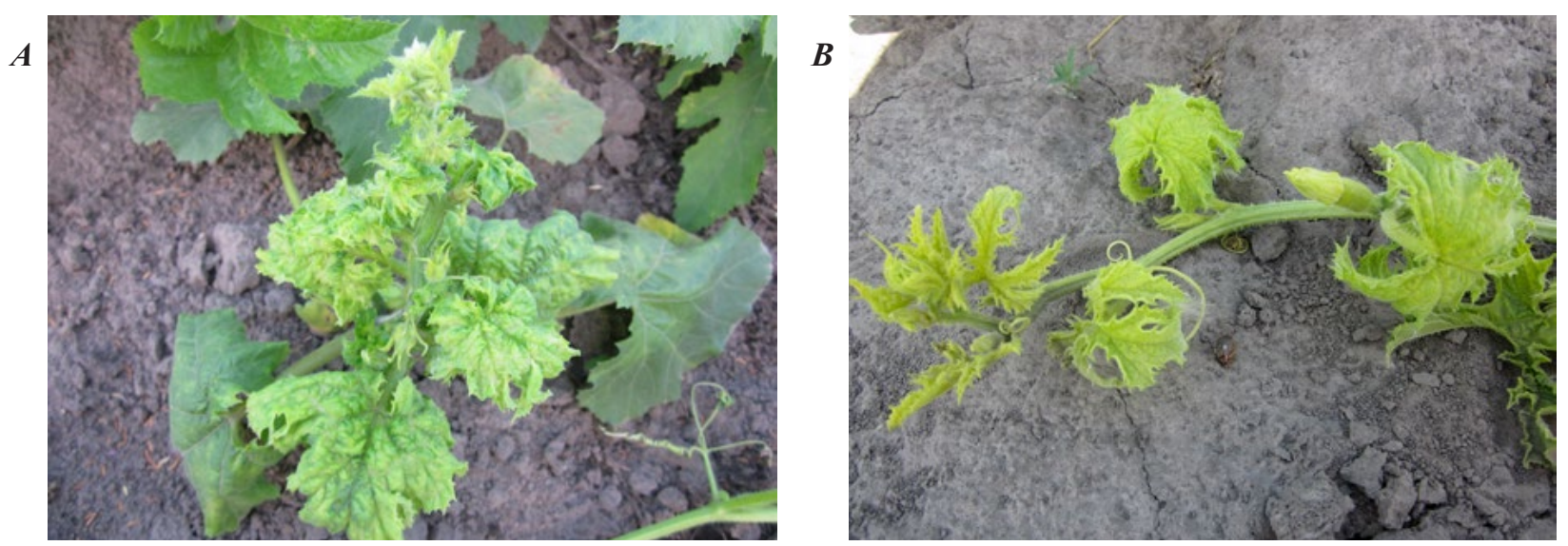

Fig. 1. Virus-like symptoms on sampled plants in field conditions (later confirmed as CMV-positive): $A-$ leaf deformation and stunting (pumpkin plant), B - leaf rolling and mosaic, and stunting (squash plant)

ers complementary to the genes of the $\mathrm{CP}, \mathrm{MP}$ and $2 \mathrm{~b}$ protein of CMV producing the amplicons with expected size of $500 \mathrm{bp}, 800 \mathrm{bp}$, and 300 bp, respectively $[9,10]$. Total RNA extraction and PCR amplification were assessed by electrophoresis in a 1.5\% agarose gel in TBE buffer $(89 \mathrm{mM}$ TRIS borate and $2 \mathrm{mM}$ EDTA, $\mathrm{pH}$ 8.3) stained with ethidium bromide. The purified amplicons were sequenced using Applied Biosystems 3730x1 DNA Analyzer with Big Dye terminators, version 3.1 (Applied Biosystems, USA).

The aligned cDNA sequences of Ukrainian CMV isolates were compared with the nucle- otide sequences of CMV strains and isolates belonging to subgroup I and II publicly available from the GenBank database (http://www. ncbi.nlm.nih.gov). The phylogenetic analysis was conducted using MEGA 6 software. The phylogenetic trees were constructed using the Neighbor-Joining method.

\section{Results and Discussion}

A total of 370 samples of cucurbit plants showing virus-like symptoms of yellow leaf mosaic, dark green spotting, leaf deformation, vein banding, and/or fruit malformation (Fig. 1) were collected in different sites.

\section{Table 1. Ukrainian isolates of CMV used for phylogenetic analysis}

\begin{tabular}{|c|c|c|c|c|}
\hline Isolate & Host & Symptoms & Sampling region & Sampling year \\
\hline CMV-Ukr-2114 & $\begin{array}{l}\text { Squash } \\
\text { (Cucurbita pepo L.) }\end{array}$ & $\begin{array}{l}\text { Light green mosaic, vein banding, fruit } \\
\text { malformation }\end{array}$ & Cherkasy & 2014 \\
\hline CMV-Ukr-28 & $\begin{array}{l}\text { Squash } \\
\text { (Cucurbita pepo L.) }\end{array}$ & $\begin{array}{l}\text { Yellow-green mosaic, leaf rolling and } \\
\text { yellowing, fruit malformation with knobs }\end{array}$ & Lviv & 2015 \\
\hline CMV-Ukr-36 & $\begin{array}{l}\text { Cucumber } \\
\text { (Cucumis sativus L.) }\end{array}$ & Light green mosaic, fruit malformation & Poltava & 2015 \\
\hline CMV-Ukr-58 & $\begin{array}{l}\text { Squash } \\
\text { (Cucurbita pepo L.) }\end{array}$ & Fruit malformation & Cherkasy & 2015 \\
\hline
\end{tabular}


CMV was detected by DAS-ELISA in large part of the collected plant samples $(>50 \%)$ including pumpkin, squash, and cucumber.

A
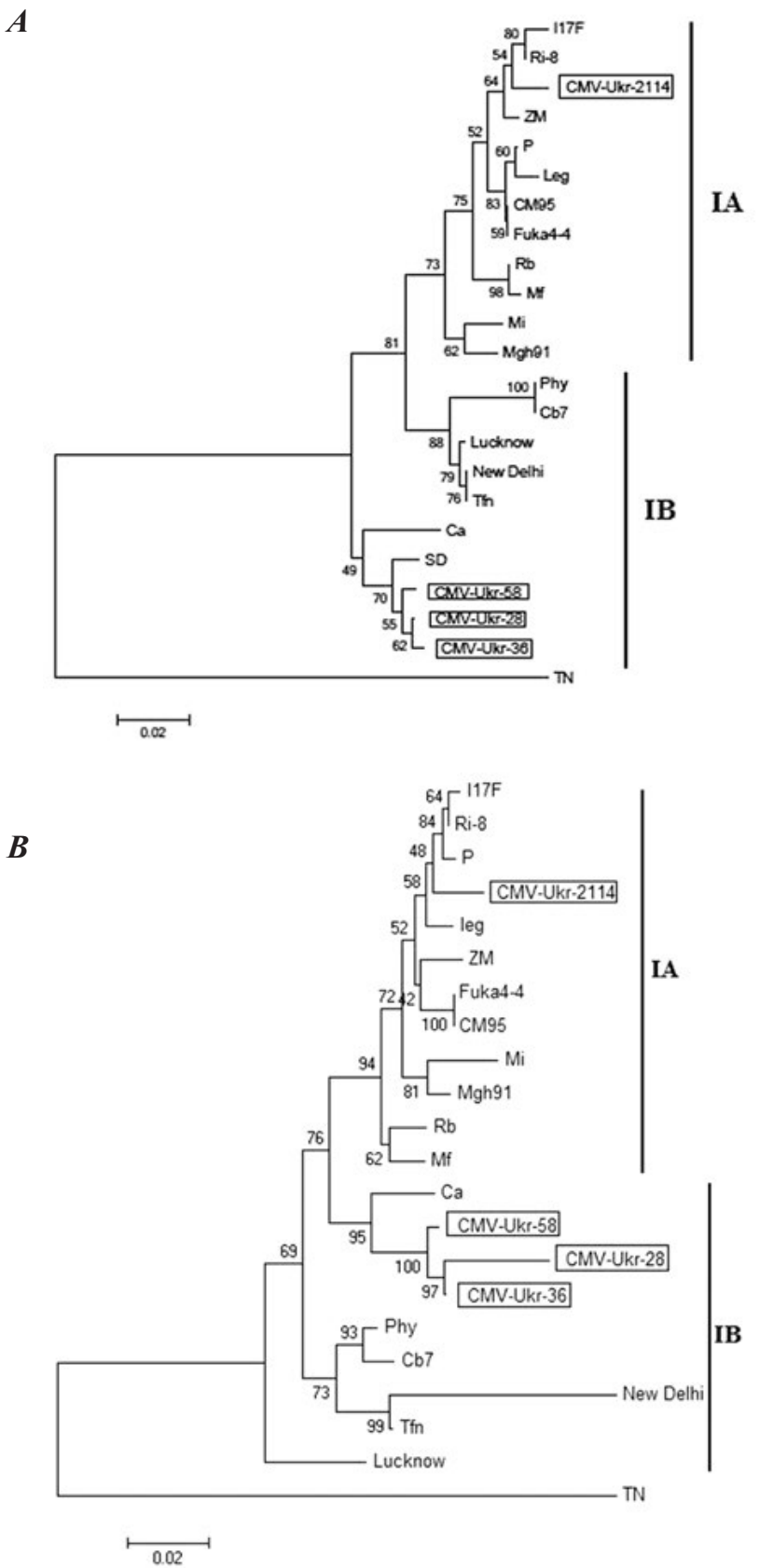
IA
For further investigations, four samples were selected differing either by their native hosts or year of sampling (Table 1).

Partial nucleotide sequences of the $C P, M P$ and $2 b$ genes responsible for pathogenicity of CMV were amplified for four isolates designated CMV-Ukr-2114, CMV-Ukr-28, CMVUkr-36, and CMV-Ukr-58 (see Table 1).

The nucleotide sequences of CMV strains available from the GenBank database were used when constructing the phylogenetic trees. These strains originate from different countries and are considered as typical representatives of the IA and IB subgroups (Fig. 2). Strain TN (AB176847) belonging to the subgroup II was used as the outgroup.

Fig. 2. Neighbor-Joining trees showing phylogenetic relationships among previously known strains/isolates of CMV and four Ukrainian isolates based on their partial nucleotide sequences of the coat protein $(\mathrm{A})$, movement protein $(\mathrm{B})$ and $2 \mathrm{~b}$ protein $(\mathrm{C})$ genes. Bootstrap values are shown near the branches. Ukrainian isolates are shown in squares

C

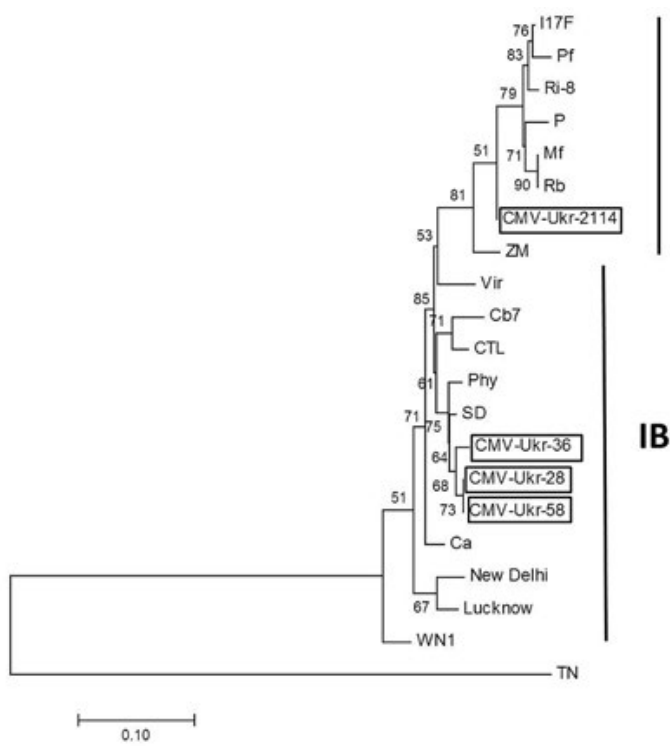

IA

IB 
Regardless of the gene used for phylogenetic analysis, the trees (Fig.2, A, B and C) had similar topology. In parallel to our previous results [6], Ukrainian isolates belonged to the subgroups IA (isolate CMV-Ukr-2114) and IB (isolates CMV-Ukr-28, CMV-Ukr-36, and CMV-Ukr-58).

Depending on the gene used for phylogenetic analysis, Ukrainian subgroup IB isolates changed their positions within the subcluster:

Table 2. Nucleotide identity (\%) of partial nucleotide sequences of $C P, M P$ and $2 b$ genes of Ukrainian isolates of CMV. The highest percentage of pairwise identity is shown in bold

\begin{tabular}{|c|c|c|c|c|}
\hline \multicolumn{5}{|c|}{$C P$} \\
\hline Isolate & 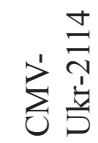 & $\sum_{i}^{1} \stackrel{\infty}{i}$ & $\sum_{i}^{1} \frac{0}{n}$ & 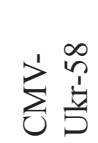 \\
\hline CMV-Ukr-2114 & 100 & & & \\
\hline CMV-Ukr-28 & 93 & 100 & & \\
\hline CMV-Ukr-36 & 92,7 & 99,7 & 100 & \\
\hline CMV-Ukr-58 & 93 & 98,4 & 99 & 100 \\
\hline \multicolumn{5}{|c|}{$M P$} \\
\hline Isolate & 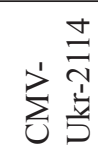 & $\sum^{1} \stackrel{\infty}{\frac{1}{t}}$ & $\sum_{0}^{1} \frac{0}{n}$ & 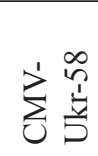 \\
\hline CMV-Ukr-2114 & 100 & & & \\
\hline CMV-Ukr-28 & 90,2 & 100 & & \\
\hline CMV-Ukr-36 & 96 & 97,4 & 100 & \\
\hline CMV-Ukr-58 & 96,4 & 96,7 & 99,2 & 100 \\
\hline \multicolumn{5}{|c|}{$2 b$} \\
\hline Isolate & 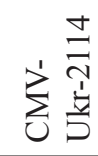 & $\sum^{1} \stackrel{\infty}{\frac{1}{t}}$ & $\sum_{0}^{1} \frac{0}{n}$ & 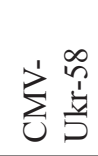 \\
\hline CMV-Ukr-2114 & 100 & & & \\
\hline CMV-Ukr-28 & 88 & 100 & & \\
\hline CMV-Ukr-36 & 85 & 95,4 & 100 & \\
\hline CMV-Ukr-58 & 88 & 99,6 & 95 & 100 \\
\hline
\end{tabular}

isolate CMV-Ukr-28 was grouped together with isolate $\mathrm{CMV}-\mathrm{Ukr}-36$ on the $C P$ - and $M P$ based trees (Fig.2, A and B), but it was grouped with isolate CMV-Ukr-58 on the $2 b$-based tree (Fig.2, C). This finding, however, had no effect on the overall pattern of clustering of Ukrainian isolates of CMV.

This tendency was also obvious when comparing pairwise identities for the obtained CMV amplicons. Thus, the $C P, M P$ and $2 b$ gene sequences of isolates belonging to the same subgroup (subgroup IB, isolates CMVUkr-28, CMV-Ukr-36, and CMV-Ukr-58) showed high intragroup nucleotide identity totaling $95-99 \%$ and generally demonstrated good correlation of clustering irrespective of the gene analyzed. For the $C P$ gene region, isolates CMV-Ukr-28 and CMV-Ukr-36 were most homologous $(99,7 \%)$, for the $M P$ gene region - isolates CMV-Ukr-36 and CMVUkr-58 (99,2\%), when isolates CMV-Ukr-58 and CMV-Ukr-28 were most identical in the $2 b$ gene region $(99,6 \%)$ (Table 2$)$. High overall homology of Ukrainian isolates CMVUkr-28, CMV-Ukr-36, and CMV-Ukr-58 (all belonging to the subgroup IB) suggests that they should be attributed to the same strain of CMV which circulates in different regions of Ukraine and is subjected to microevolutionary changes.

Expectedly, isolate CMV-Ukr-2114 demonstrated significantly lower nucleotide identity with the remaining three Ukrainian isolates as it was grouped into the genetically distinct subgroup IA (Fig.2, Table 2).

Further analysis of the translated amino acid sequences revealed unique amino acid substitutions in the $2 \mathrm{~b}$ protein: serine $->$ isoleucine at the position 42 for isolates CMV-Ukr-28 and 
CMV-Ukr-58, and serine -> leucine at the position 62 for CMV-Ukr-36.

The $2 \mathrm{~b}$ protein is a suppressor of the posttranscriptional gene silencing required for host-specific 'protective' reactions of the virus in order to evade plant defenses. In view of this we supposed that the amino acid substitutions in the $2 \mathrm{~b}$ protein of isolates CMV-Ukr-28, CMV-Ukr-36 and CMV-Ukr-58 may be connected with the origin of the virus (see Table 1) and are required for its efficient replication in these plants. Isolates CMV-Ukr-28 and CMVUkr-58 were collected from Cucurbita pepo plants, when isolate CMV-Ukr-36 was obtained from Cucumis sativus.

To check this hypothesis, we intentionally selected the $2 b$ protein sequences of IB strains and isolates of CMV collected from various hosts of 5 different families, and constructed the phylogenetic tree (Fig. 3).

Most of the host plants were from the Cucurbitaceae and Solanaceae families (which were of special interest in this project), when some were brassicas including wild-growing plant species as well as crops which are often cultivated nearby cucurbits and solanaceous plants. Strain TN (AB176847) was used as the outgroup. However, the resultant phylogenetic tree revealed no significant patterns between host type and respective amino acid substitutions (Fig. 3).

Overall, CMV was found abundant in every sampled region in Ukraine where it infected various host plants with different systemic symptoms. Commonness of CMV infection of susceptible plants in field conditions suggests a long-term circulation of the pathogen with possible frequent co-infection of hosts by the isolates belonging to the different phyloge-

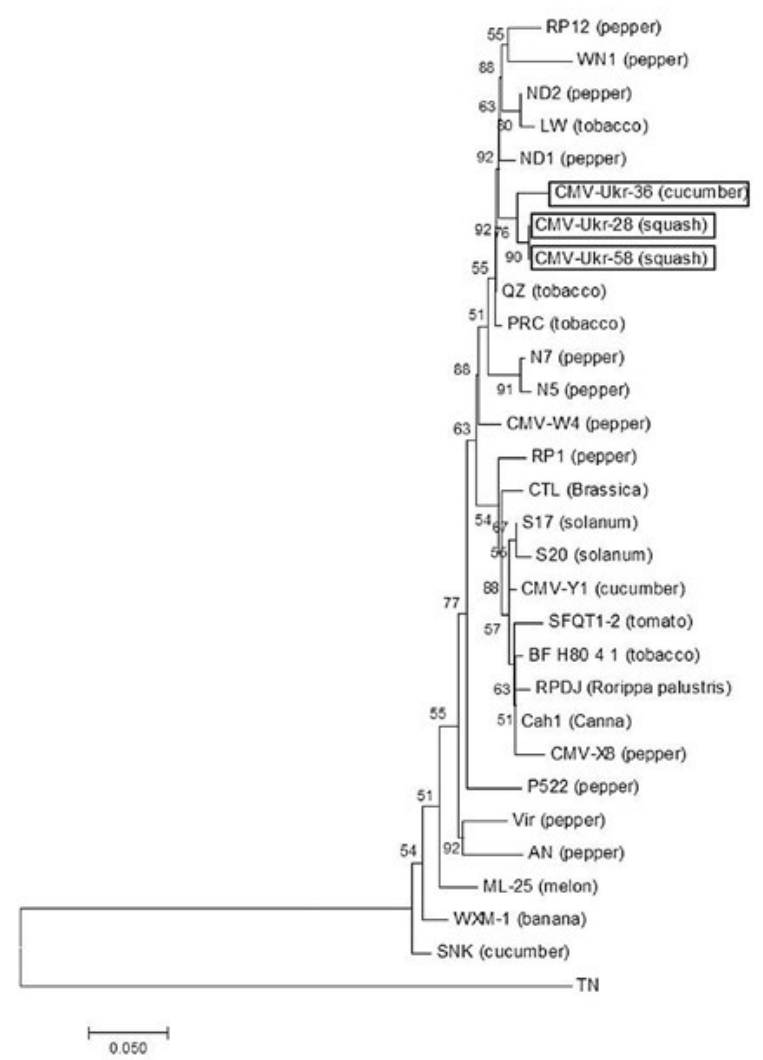

Fig. 3. Neighbor-Joining tree showing host-(in)dependent phylogenetic relationships of Ukrainian IB isolates and other known strains of CMV based on the translated amino acid sequences of the $2 b$ gene. Bootstrap values are shown at the nodes. Ukrainian isolates are shown in squares

netic subgroups. In this work, isolates from both subgroups IA and IB were found and analyzed. Subsequently, this may lead to the recombination and reassortment between such isolates generating new and possibly more severe virus variants [10].

Genetic groups and subgroups of CMV isolates differ geographically. Subgroup IA and group II have worldwide distribution and the group I isolates typically prevail $(\sim 80 \%)$, when the subgroup IB isolates were initially restric- 
ted to Easy Asia which was considered their place of origin [5]. During the last years, members of the subgroup IB were also detected in European countries, especially in Mediterranean area, Poland, but with lower rate [11].

CMV isolates circulating in Ukraine belong to the most frequent phylogenetic subgroups also common for other European countries. Phylogenetic analysis based on three virus genes showed that 3 out of 4 isolates of CMV (isolates CMV-Ukr-28, CMV-Ukr-36 and CMV-Ukr-58) were attributed to the subgroup IB, when the isolate CMV-Ukr-2114 remained the only representative of the subgroup IA found in this study. Similar clustering of the isolates of CMV-Ukr-28, CMV-Ukr-36, CMVUkr-58 on the $C P$ - and $M P$-based phylogenetic trees as well as their high nucleotide identity may imply that these isolates may recently have had a common ancestor which had passed through a bottleneck event [12].

In the previous work, we described two CMV isolates, Ukr-sq13 (GenBank Accession Number KJ921837) and Ukr-tom2 (GenBank Accession Number KJ921838), also belonging to the subgroup IB [13]. Comparison of the isolates identified in this research (with the exception of CMV-Ukr-2114 isolate from IA subgroup) with those described previously (Table 3) showed their high mutual homology $(>99 \%)$ suggesting that all these isolates were the IB isolates belonging to the same virus strain. Taking this altogether, we suggest that IB isolates of CMV prevail in Ukraine. Similarly to many other European countries, subgroup II isolates have not been found in Ukraine since they weren't predominant in this region [14].

Genetic differences found among the subgroup IB isolates and the discovery of the only subgroup IA isolate in this study (Fig. 2, Table 1) may be indicative of the separate origins of CMV infection in Ukraine. This is in line with our findings of two new amino acid substitutions in the $2 \mathrm{~b}$ protein for isolates CMV-Ukr-28 and CMV-Ukr-58 confirming the never-ending process of natural selection in Ukrainian ecosystems.

\section{Conclusions}

In summary, we used incomplete sequences of three viral genes for the phylogenetic analysis of the isolates of Cucumber mosaic virus circulating in Ukraine. These isolates belong to

Table 3. Comparison of Ukrainian isolates of CMV based on the nucleotide identity (\%) of partial nucleotide sequences of their $C P$ gene

\begin{tabular}{|l|c|c|c|c|c|c|}
\hline \multicolumn{1}{|c|}{ Isolate } & $\begin{array}{c}\text { CMV- } \\
\text { Ukr-2114 }\end{array}$ & CMV-Ukr-28 & CMV-Ukr-36 & CMV-Ukr-58 & $\begin{array}{c}\text { CMV-Ukr- } \\
\text { tom2 }\end{array}$ & $\begin{array}{c}\text { CMV-Ukr- } \\
\text { sq13 }\end{array}$ \\
\hline CMV-Ukr-2114 & 100 & & & & & \\
CMV-Ukr-28 & 93 & 100 & & & & \\
CMV-Ukr-36 & 92,7 & 99,7 & 100 & & & \\
CMV-Ukr-58 & 93 & 98,4 & 99 & 100 & & \\
CMV-Ukr-tom2 & 90 & $\mathbf{9 9 , 5}$ & $\mathbf{9 9 , 8}$ & $\mathbf{9 8 , 5}$ & 100 & \\
CMV-Ukr-sq13 & 90,4 & $\mathbf{9 9 , 8}$ & $\mathbf{9 9 , 5}$ & $\mathbf{9 9}$ & 99 & 100 \\
\hline
\end{tabular}

High homology values for all IB isolates from Ukraine are shown in bold. 
the most widespread phylogenetic subgroups IA and IB which are also found in other European countries. The unique amino acid substitutions in $2 \mathrm{~b}$ protein sequences of two CMV isolates were described. The obtained data may indicate separate routes of CMV infection, as well as the ongoing virus microevolution in Ukraine.

\section{Acknowledgements}

The authors are grateful to Dr. I.I. Boubriak for his invaluable support and technical assistance.

\section{REFERENCES}

1. Arafati N, Farzadfar S, Pourrahim R. Characterization of coat protein gene of Cucumber mosaic virus isolates in Iran. Iran J Biotech. 2013; 11(2): 109-14.

2. Roossinck MJ. Evolutionary history of Cucumber mosaic virus deduced by phylogenetic analyses. J Virol. 2002;76(7):3382-7.

3. Lecoq H, Desbiez C. Viruses of cucurbit crops in the Mediterranean region: an ever-changing picture. Adv Virus Res. 2012;84:67-126.

4. Palukaitis P, García-Arenal F. Cucumoviruses. Adv Virus Res. 2003;62:241-323.

5. Roossinck MJ, Zhang L, Hellwald KH. Rearrangements in the 5' nontranslated region and phylogenetic analyses of cucumber mosaic virus RNA 3 indicate radial evolution of three subgroups. $J$ Virol. 1999;73(8):6752-8.

6. Tymchyshyn O, Shevchenko T, Budzanivska I, Polishchuk $V$. Viruses infecting cucurbits in Ukraine and their phylogenetic analysis. 13th International Plant Virus Epidemiology Symposium. Abstracts. 2016; $148 \mathrm{p}$.

7. Zitikaitè I, Staniulis J, Urbanavičienè L, Žižytė M. Cucumber mosaic virus identification in pumpkin plants. Žemdirbystè =Agriculture. 2011; 98(4): 421-6.

8. Clark MF, Adams AN. Characteristics of the microplate method of enzyme-linked immunosorbent assay for the detection of plant viruses. $J$ Gen Virol. 1977;34(3):475-83.
9. Barba M, Jelkman W, Martin R. Detection of virus and virus-like diseases of fruit trees and small fruit crops. Acta Hortic. 1998; 472: 759-783.

10. Kim, M-K, Kwak H-R, Jeong $S-G$, Ko S-J, Lee $S-H$, Kim J-S, Kim K-H, Choi J-K, Choi Ho-S, Cha B-J. Characteristics of Cucumber mosaic virus Infecting Zucchini in Korea. Plant Pathol J. 2010; 26(2):139-48.

11. Berniak H, Malinowski T, Kaminska M. Comparison of ELISA and RT-PCR assays for detection and identification of cucumber mosaic virus (CMV) isolates infecting horticultural crops in Poland. $J$ Fruit Ornam Plant Res. 2009; 17(2): 5-20.

12. Ali A, Li H, Schneider WL, Sherman DJ, Gray S, Smith D, Roossinck MJ. Analysis of genetic bottlenecks during horizontal transmission of Cucumber mosaic virus. J Virol. 2006;80(17):8345-50.

13. Shevchenko TP, Tymchyshyn OV, AlDalain E, Bysov AS, Budzanivska IG, Shevchenko OV, Polishchuk VP. The first evidence of subgroup IB isolates of Cucumber mosaic virus in Ukraine. Biopolym Cell. 2015; 31(1); 57-62.

14. Kumari R, Bhardwaj P, Singh L, Zaidi AA, Hallan V. Biological and Molecular Characterization of $\mathrm{Cu}-$ cumber mosaic virus Subgroup II Isolate Causing Severe Mosaic in Cucumber. Indian J Virol. 2013; 24(1):27-34.

\section{Молекулярна характеристика та філогенетичний аналіз українських ізолятів вірусу огіркової мозаїки із використанням часткових послідовностей трьох генів}

Т. П. Шевченко, О. В. Тимчишин, Ю. А. Косенко, І. Г. Будзанівська, О. В. Шевченко, В. П. Поліщук

Мета. Провести філогенетичний аналіз українських ізолятів Cucumber mosaic virus з використанням неповних послідовностей декількох генів вірусу. Методи. Імуноферментний аналіз, полімеразна ланцюгова реакція зі зворотною транскрипцією, секвенування ДНК та філогенетичний аналіз. Результати. Зразки рослин із симптомами було відібрано з різних регіонів України та протестовано на наявність вірусу огіркової мозаїки ВОМ. Отримано й проаналізовано нуклеотидні часткові послідовності генів капсидного білка, білків руху та білка $2 \mathrm{~b}$ чотирьох ізолятів ВОМ. Показано, що ці ізоляти належать до підгруп IA та IB. Відсоток поді- 
бності українських ізолятів за нуклеотидними послідовностями генів капсидного білка, білка руху та білка $2 b$ був високим у межах підгруп. Виявлено унікальні заміни у амінокислотних послідовностях білка $2 \mathrm{~b}$ ізолятів CMV-Ukr-28 і CMV-Ukr-58, які не пов'язані з рослиною-хазяїном. Висновки. Ізоляти вірусу огіркової мозаїки, які циркулюють в Україні та описані в роботі, належать до найбільш розповсюджених філогенетичних груп, які представлені і в інших європейських країнах. Отримані дані можуть вказувати на декілька окремих джерел проникнення ВОМ на територію України, а також на поточну мікроеволюцію ВОМ в Україні.

К л ю ч о в і с л о в а: вірус огіркової мозаїки, ген капсидного білку, ген білка руху, ген білка $2 b$, філогенетичний аналіз.

\section{Молекулярная характеристика и филогенетический анализ украинских изолятов вируса огуречной мозаики с использованием частичных последовательностей трех генов}

Т. П. Шевченко, О. В. Тымчишин, Ю. А. Косенко, И. Г. Будзанивская, А. В. Шевченко, В. П. Полищук

Цель. Провести филогенетический анализ украинских изолятов Cucumber mosaic virus с использованием неполных последовательностей нескольких генов вируса.
Методы. Иммуноферментный анализ, полимеразная цепная реакция с обратной транскрипцией, секвенирование ДНК и филогенетический анализ. Результаты. Образцы растений с симптомами были отобраны в разных регионах Украины и протестированны на наличие ВОМ. Получены и проанализированы частичные нуклеотидные последовательности генов капсидного белка, белка движения и белка $2 \mathrm{~b}$ четырех украинских изолятов ВОМ. Показано, что эти изоляты принадлежат к подгруппам IA и IB. Процент сходства украинский изолятов по нуклеотидным последовательностям генов капсидного белка, белка движения и белка $2 \mathrm{~b}$ был высоким в пределах групп. Обнаружены уникальные замены в аминокислотных последовательностях изолятов $C M V$-Ukr-28 и CMV-Ukr-58, не связаные с растением-хозяином. Выводы. Изоляты вируса огуречной мозаики, циркулирующие в Украине и описаные в работе, принадлежат к наиболее распространенным филогенетическим подгруппам IA и IB, которые представлены и в других европейских странах. Полученные данные могут указывать на несколько отдельных источников проникновения ВОМ на территорию Украины, а также на текущую микроэволюцию вируса в Украине.

К л юч е в ы е с л о в а: вирус огуречной мозаики, ген капсидного белка, ген белка движения, ген белка 2b, филогенетический анализ.

Received 02.09.2017 